
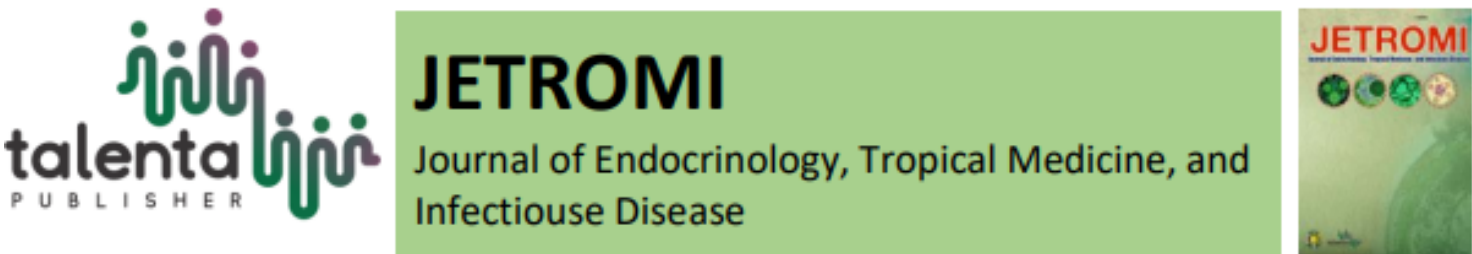

\title{
Characteristics of Lung Cancer Patients in Haji Adam Malik General Hospital Medan in 2016-2018
}

\author{
Satthiyabalan Sivabalan ${ }^{1}$, Causa Trisna Mariedina ${ }^{2}$ \\ 1,2, Department of Pathology Anatomy, Faculty of Medicine, Universitas Sumatera Utara
}

\begin{abstract}
Lung cancer is a malignant disease in the lung where abnormalities can lead to cell proliferation that cannot be controlled. This study was conducted to determine the characteristics of lung cancer patients in Haji Adam Malik General Hospital Medan in 20162018 with a case series approach. The study population was 311 lung cancer patients using Total Sampling method. The tendency of inpatient lung cancer patients visiting H. Adam Malik General Hospital Medan in 2016-2018 has decreased. The highest proportion of patients with lung cancer based on sociodemography obtained 65-69 years old age group, men with 3: 1 sex ratio, work of farmers, living outside the city of Medan, the main complaint was more than one complaint, had a history of smoking, no pleural effusion occurred, the type of adenocarcinoma histology and the method of taking a cytological fluid specimen. There was a statistically significant relationship between age with sex, sex with occupation, sex with smoking history, occupation with primary complaints, occupation with smoking history, and histology type by specimen collection and there rest have no statistically significant difference.
\end{abstract}

Keyword: Lung cancer, Characteristics, Malignancy, Respiratory tract

\begin{abstract}
Abstrak. Kanker paru adalah penyakit keganasan pada paru, yang mengakibatkan proliferasi sel yang tidak dapat dikendalikan. Penelitian ini dilakukan untuk mengetahui karakteristik penderita kanker paru di RSUP Haji Adam Malik Medan tahun 2016-2018 dengan pendekatan case series. Sampel penelitian sebanyak 311 data penderita kanker paru, diambil dengan metode Total Sampling. Kecenderungan kunjungan penderita kanker paru rawat inap di RSUP H. Adam Malik Medan tahun 2016-2018 mengalami penurunan. Proporsi penderita kanker paru berdsarkan sosiodemografi tertinggi diperoleh kelompok umur 65-69 tahun, laki-laki dengan sex ratio $3: 1$, pekerjaan petani, yang tinggal di luar Kota Medan, keluhan utama lebih dari satu keluhan, memiliki riwayat merokok, tidak terjadi efusi pleura, tipe histologi adenocarcinoma dan cara pengambilan spesimen secara sitologi cairan. Terdapat hubungan yang signifikan secara statistik antara umur dengan jenis kelamin, jenis kelamin dengan pekerjaan, jenis kelamin dengan riwayat merokok, pekerjaan dengan keluhan utama, pekerjaan dengan riwayat merokok, dan tipe histologi dengan cara pengambilan specimen dan yang selebihnya tidak ada perbedaan yang signifikan secara statistic.
\end{abstract}

Kata Kunci: Kanker paru, Karakteristik, Keganasan, Saluran nafas

Received 19 December 2019| Revised 29 January 2020 | Accepted 01 February 2020

Corresponding author at:Faculty of Medicine, Universitas Sumatera Utara, H. Adam Malik Hospital, Jalan Bunga Lau No 17, Medan 20136, Indonesia

satthiyabalansivabalan@gmail.com 


\section{Introduction}

Lung cancer is a malignant disease in the lungs, including malignancies originating from the lungs themselves and malignancies from outside the lungs which can result in cell proliferation that cannot be controlled. This disease is often found at an advanced stage with fatal consequences [1].

Lung cancer is the second most common cancer in men and women. About $25 \%$ of all cancers are lung cancer. The epidemiological survey reports that the difference in male and female cases is $5: 1$. In general, it is reported that approximately $91 \%$ of lung cancer sufferers are sufferers over 40 years [2]. Employment is also a risk factor for lung cancer [3]. Effects from industrial exposure can only be seen after 15-20 years [4]. Besides that, carcinogenic inhalation which is a big risk factor for lung cancer is cigarette [5].

There is enough evidence to link cigarettes with bronchogenic carcinomas, especially squamous cell carcinoma of bronchogenic carcinomas and small cell carcinomas [4]. Cough is experienced by $85 \%$ of people with lung cancer. Shortness of breath generally results from tumor obstruction in the main bronchus or trachea.

Based on the World Health Organization (WHO) 2015, the classification of lung cancer divided into 2, namely non-small cell carcinoma and small cell carcinoma. There are several examinations or ways to take specimens that can be done to diagnose lung cancer divided into two, namely cytopathology and histopathology [6]. Therefore, the author would like to conduct research on the characteristics of lung cancer sufferers in Haji Adam Malik General Hospital Medan 20162018.

\section{Method}

This research uses descriptive research method with a case series approach that aims to determine the characteristics of lung cancer sufferers in Haji Adam Malik General Hospital Medan in 20162018. Data collection was carried out in June to November 2019 conducted at the General Hospital of Haji Adam Malik Medan. The population of this study was 311 lung cancer patients using total sampling method with secondary data obtained from the status card of the medical record section examined by anatomical pathology, then recorded and tabulated in accordance with the variables studied. The data collected was processed and analyzed using the SPSS computer program, where univariate analysis was descriptively and bivariate analysis used the Chi-square test. 


\section{Results}

Table 1 Proportion of Lung Cancer Patients by Year

\begin{tabular}{ccc}
\hline Year & $\mathrm{n}$ & $\%$ \\
\hline 2016 & 102 & 32.8 \\
2017 & 126 & 40.5 \\
2018 & 83 & 26.7 \\
Total & 311 & 100.0 \\
\hline
\end{tabular}

In table 1, the highest proportion of lung cancer patients hospitalized was in 2017 at $40.5 \%$, and lowest in 2018 at $26.7 \%$.

Table 2 Age by Gender in year 2016-2018

\begin{tabular}{cccccccc}
\hline \multirow{2}{*}{ Age } & \multicolumn{9}{c}{ Gender } & \multicolumn{2}{c}{ Total } & \multirow{2}{*}{ P Value } \\
\cline { 2 - 6 } & \multicolumn{2}{c}{ Man } & \multicolumn{2}{c}{ Women } & & \\
\cline { 2 - 6 } & $\mathrm{n}$ & $\%$ & $\mathrm{n}$ & $\%$ & $\mathrm{n}$ & $\%$ & \\
\hline $30-34$ & 1 & 100 & 0 & 0.0 & 1 & 100 & \\
$35-39$ & 1 & 33.3 & 2 & 66.7 & 3 & 100 & \\
$40-44$ & 6 & 46.2 & 7 & 53.8 & 13 & 100 & \\
$45-49$ & 10 & 62.5 & 6 & 37.5 & 16 & 100 & \\
$50-54$ & 41 & 73.2 & 15 & 26.8 & 56 & 100 & \multirow{2}{*}{0.015} \\
$55-59$ & 44 & 80.0 & 11 & 20.0 & 55 & 100 & \\
$60-64$ & 36 & 72.0 & 14 & 28.0 & 50 & 100 & \\
$65-69$ & 63 & 90.0 & 7 & 10.0 & 70 & 100 & \\
$70-74$ & 13 & 76.5 & 4 & 23.5 & 17 & 100 & \\
$\geq 75$ & 24 & 80.0 & 6 & 20.0 & 30 & 100 & \\
\hline
\end{tabular}

In table 2, the highest age proportion of lung cancer patients in the 65-69 year age group was 70 people $(22.5 \%)$, the lowest in the 30-34\% year age group of 1 person $(0.3 \%)$ and 239 people (76.8\%) than 72 women (23.2\%). Sex ratio of lung cancer sufferers $\frac{239}{72}$ or about 3:1 shows the number of lung cancer sufferers is higher for male.

Table 3 Gender Based on Occupation

\begin{tabular}{|c|c|c|c|c|c|c|c|c|c|c|c|c|c|c|c|}
\hline \multirow{3}{*}{ G } & \multicolumn{12}{|c|}{ Occupation } & \multirow{2}{*}{\multicolumn{2}{|c|}{ TT }} & \multirow{3}{*}{$\mathrm{P}$} \\
\hline & \multicolumn{2}{|c|}{ RT } & \multicolumn{2}{|c|}{ PE } & \multicolumn{2}{|c|}{ ET } & \multicolumn{2}{|c|}{ FM } & \multicolumn{2}{|c|}{ UN } & \multicolumn{2}{|c|}{ NR } & & & \\
\hline & $\mathrm{n}$ & $\%$ & $\mathrm{n}$ & $\%$ & $\mathrm{n}$ & $\%$ & $\mathrm{n}$ & $\%$ & $\mathrm{n}$ & $\%$ & $\mathrm{n}$ & $\%$ & $\mathrm{n}$ & $\%$ & \\
\hline M & 17 & 7.1 & 26 & 10.9 & 72 & 30.1 & 90 & 37.7 & 1 & 0.4 & 33 & 13.8 & 239 & 100 & $<$ \\
\hline W & 1 & 1.4 & 3 & 4.2 & 5 & 6.9 & 11 & 15.3 & 43 & 59.7 & 9 & 12.5 & 72 & 100 & 0.001 \\
\hline
\end{tabular}

Information: $\mathrm{G}=$ Gender, $\mathrm{UN}=$ Unemployed, $\mathrm{RT}=$ Retired, $\mathrm{NR}=$ Not Recorded, $\mathrm{PE}=$ Private Employees, $\mathrm{TT}=$ Total, $\mathrm{ET}=$ Entrepreneur, $\mathrm{M}=\mathrm{Man}, \mathrm{FM}=$ Farmer, $\mathrm{W}=$ Women, $\mathrm{P}=\mathrm{P}$ Value

In table 3, highest proportion of occupational lung cancer sufferers was 101 people (32.5\%) farmers and the lowest were 18 people (5.8\%) who are retired. Out of all male lung cancer sufferers, the highest is $90 \%$ (37.7\%) of farmers' and the lowest is 1 person $(0.4 \%)$ unemployed. Of all female lung cancer sufferers, the highest was 43 people who were unemployed (59.7\%) and the lowest was 1 person who retired (1.4\%). 
Table 4 Proportion of Lung Cancer Patients Based on Residence

\begin{tabular}{ccc}
\hline Residence & $\mathrm{n}$ & $\%$ \\
\hline Kota Medan & 65 & 20.9 \\
Outside kota Medan & 246 & 79.1 \\
Total & 311 & 100.0 \\
\hline
\end{tabular}

In table 4, the higher proportion of residence of lung cancer sufferers is 246 people $(79.1 \%)$ who live outside the city of Medan than 65 people living in the city of Medan (20.9\%).

Table 5 Occupation based on Major Complaints

\begin{tabular}{|c|c|c|c|c|c|c|c|c|c|}
\hline \multirow{3}{*}{ Occupation } & \multicolumn{6}{|c|}{ Main Complaint } & & & \multirow{3}{*}{ P Value } \\
\hline & \multicolumn{2}{|c|}{ Dyspnea } & \multicolumn{2}{|c|}{ Cough } & \multicolumn{2}{|c|}{$\begin{array}{l}\text { > } 1 \text { Main } \\
\text { Complaint }\end{array}$} & \multicolumn{2}{|c|}{ Total } & \\
\hline & $\mathrm{n}$ & $\%$ & $\mathrm{n}$ & $\%$ & $\mathrm{n}$ & $\%$ & $\mathrm{n}$ & $\%$ & \\
\hline Retired & 0 & 0.0 & 2 & 11.1 & 16 & 88.9 & 18 & 100 & \\
\hline Private Employees & 4 & 13.8 & 3 & 10.3 & 22 & 75.9 & 29 & 100 & \\
\hline Entrepreneurs & 4 & 5.2 & 0 & 0.0 & 73 & 94.8 & 77 & 100 & 0,010 \\
\hline Farmers & 2 & 2.0 & 5 & 5.0 & 94 & 93.1 & 101 & 100 & 0.019 \\
\hline Unemployed & 4 & 9.1 & 1 & 2.3 & 39 & 88.6 & 44 & 100 & \\
\hline Not Recorded & 0 & 0.0 & 2 & 4.8 & 40 & 95.2 & 42 & 100 & \\
\hline
\end{tabular}

In table 5, the highest proportion of main complaints of lung cancer sufferers was more than one main complaint of 284 people (91.3\%) and the lowest was coughing of 13 people (4.2\%).

Table 6 Occupation Based on Smoking History

\begin{tabular}{cccccccc}
\hline \multirow{2}{*}{ Occupation } & \multicolumn{4}{c}{ Smoking History } & \multicolumn{2}{c}{ Total } & \multirow{2}{*}{ P Value } \\
\cline { 2 - 5 } & \multicolumn{2}{c}{ Smoker } & \multicolumn{2}{c}{ Non Smoker } & & \\
\cline { 2 - 6 } & $\mathrm{n}$ & $\%$ & $\mathrm{n}$ & $\%$ & $\mathrm{n}$ & $\%$ & \\
\hline Retired & 17 & 94.4 & 1 & 5.6 & 18 & 100 & \\
Private Employees & 24 & 82.8 & 5 & 17.2 & 29 & 100 & \\
Entrepreneur & 74 & 96.1 & 3 & 3.9 & 77 & 100 & $<0.001$ \\
Farmers & 91 & 90.1 & 10 & 9.9 & 101 & 100 & \\
Unemployed & 17 & 38.6 & 27 & 61.4 & 44 & 100 & \\
Not Recorded & 36 & 85.7 & 6 & 14.3 & 42 & 100 & \\
\hline
\end{tabular}

In table 6, a higher proportion of smoking history sufferers of lung cancer were those who smoked as many as 259 people (83.3\%) than those who didn't smoke with 52 people $(16.7 \%)$. Out of all lung cancer sufferers whose occupations are retired, private employees, self-employed, farmers and are not recorded, the highest is with a history of smoking, while those who did not work, the highest was with a history of not smoking. 
Table 7 Proportion of Lung Cancer Patients Based on Pleural Effusion

\begin{tabular}{ccc}
\hline Pleural Effusion & $\mathrm{n}$ & $\%$ \\
\hline$(+)$ & 16 & 5.1 \\
$(-)$ & 295 & 94.9 \\
Total & 311 & 100.0 \\
\hline
\end{tabular}

In table 7, a higher proportion of pleural effusions in lung cancer patients is 295 people (94.9\%) who did not have pleural effusion than 16 pleura effusions (5.1\%).

Table 8 Proportion of Lung Cancer Patients by Histology Type

\begin{tabular}{ccc}
\hline Histology Type & $\mathrm{n}$ & $\%$ \\
\hline Squamous Cell Carcinoma & 79 & 25.4 \\
Adenocarcinoma & 232 & 74.6 \\
Small Cell Carcinoma & 0 & 0.0 \\
Large Cell Carcinoma & 0 & 0.0 \\
Total & 311 & 100.0 \\
\hline
\end{tabular}

In table 8 , the highest proportion of histological types of lung cancer patients was 232 adenocarcinomas, $74.6 \%$ compared to 79 squamous cell carcinomas $(25.4 \%)$.

Table 9 Proportion of Patients with Lung Cancer Based on Specimen Collection Method

\begin{tabular}{ccc}
\hline Specimen Collection Method & $\mathrm{n}$ & $\%$ \\
\hline Fluid Cytology & 223 & 71.7 \\
Cytology of AJH & 23 & 7.4 \\
Cytology of TTNA & 22 & 7.1 \\
Cytology of TBNA & 21 & 6.8 \\
Histopathology of EBUS & 0 & 0.0 \\
Histopathology of TBLB & 13 & 4.2 \\
Histopathology of TTB & 9 & 2.9 \\
Histopathology of Resection & 0 & 0.0 \\
Total & 311 & 100.0 \\
\hline
\end{tabular}

In table 9, the highest proportion of specimens for lung cancer patients was 223 fluid cytology (71.7\%) and the lowest was histopathology of TTB with 9 patients (2.9\%).

Table 10 Gender Based on Smoking History

\begin{tabular}{|c|c|c|c|c|c|c|c|}
\hline \multirow{3}{*}{ Gender } & \multicolumn{4}{|c|}{ Smoking History } & \multirow{2}{*}{\multicolumn{2}{|c|}{ Total }} & \multirow{3}{*}{ P Value } \\
\hline & \multicolumn{2}{|c|}{ Smoker } & \multicolumn{2}{|c|}{ Non Smoker } & & & \\
\hline & $\mathrm{n}$ & $\%$ & $\mathrm{n}$ & $\%$ & $\mathrm{n}$ & $\%$ & \\
\hline Man & 232 & 97.1 & 7 & 2.9 & 239 & 100 & $<0.001$ \\
\hline Women & 27 & 37.5 & 45 & 62.5 & 72 & 100 & $<0.001$ \\
\hline
\end{tabular}

In table 10, of all male lung cancer sufferers, the highest was 232 smokers $(97.1 \%)$ and all lung cancer women sufferers, the highest was 45 non-smokers $(62.5 \%)$. 
Table 11 Main Complaints Based on Smoking History

\begin{tabular}{ccccccccc}
\hline \multirow{3}{*}{ Main Complaint } & \multicolumn{4}{c}{ Smoking History } & \multirow{2}{*}{ Total } & \multirow{2}{*}{ P Value } \\
\cline { 2 - 6 } & \multicolumn{2}{c}{ Smoker } & \multicolumn{2}{c}{ Non Smoker } & & \\
\cline { 2 - 6 } & $\mathrm{n}$ & $\%$ & $\mathrm{n}$ & $\%$ & $\mathrm{n}$ & $\%$ & \\
\hline Dyspnea & 10 & 71.4 & 4 & 28.6 & 14 & 100 & \\
Cough & 13 & 100 & 0 & 0.0 & 13 & 100 & 0.013 \\
> 1 Main Complaint & 236 & 83.1 & 48 & 16.9 & 284 & 100 & \\
\hline
\end{tabular}

In table 11, whose main complaints were shortness of breath, coughing and more than one complaint all of them were highest with a history of smoking each of 10 people (71.4\%), 13 people (100\%) and 236 people $(83.1 \%)$.

Table 12 Smoking History by Histology Type

\begin{tabular}{|c|c|c|c|c|c|c|c|}
\hline \multirow{3}{*}{$\begin{array}{l}\text { Smoking } \\
\text { History }\end{array}$} & \multicolumn{4}{|c|}{ Histology Type } & \multirow{2}{*}{\multicolumn{2}{|c|}{ Total }} & \multirow{3}{*}{ P Value } \\
\hline & \multicolumn{2}{|c|}{ Squamous Cell Carcinoma } & \multicolumn{2}{|c|}{ Adenocarcinoma } & & & \\
\hline & $\mathrm{n}$ & $\%$ & $\mathrm{n}$ & $\%$ & $\mathrm{n}$ & $\%$ & \\
\hline Smoker & 71 & 27.4 & 188 & 72.6 & 259 & 100 & \multirow{2}{*}{0.069} \\
\hline Non Smoker & 8 & 15.4 & 44 & 84.6 & 52 & 100 & \\
\hline
\end{tabular}

In table 12 , both with a history of smoking and not smoking, the highest were with the type of histology of adenocarcinoma each of 188 people (72.6\%) and 44 people (84.6\%).

Table 13 Pleural Effusion Based on Histological Type

\begin{tabular}{|c|c|c|c|c|c|c|c|}
\hline \multirow{3}{*}{$\begin{array}{l}\text { Pleural } \\
\text { Effusion }\end{array}$} & \multicolumn{4}{|c|}{ Histology Type } & \multirow{2}{*}{\multicolumn{2}{|c|}{ Total }} & \multirow{3}{*}{$\begin{array}{c}\mathrm{P} \\
\text { Value }\end{array}$} \\
\hline & \multicolumn{2}{|c|}{ Squamous Cell Carcinoma } & \multicolumn{2}{|c|}{ Adenocarcinoma } & & & \\
\hline & $\mathrm{n}$ & $\%$ & $\mathrm{n}$ & $\%$ & $\mathrm{n}$ & $\%$ & \\
\hline Occurred & 1 & 6.2 & 15 & 93.8 & 16 & 100 & 0,071 \\
\hline Didn't Occur & 78 & 26.4 & 217 & 73.6 & 295 & 100 & $0.0 / 1$ \\
\hline
\end{tabular}

In table 13, both pleural effusion and pleural effusion did not occur, the highest was with the histological type of adenocarcinoma, respectively 15 people (93.8\%) and 217 people (73.6\%).

Table 14 Histological Types Based on Specimen Collection Method

\begin{tabular}{|c|c|c|c|c|c|c|c|c|c|c|c|c|c|c|c|}
\hline \multirow{3}{*}{ HT } & \multicolumn{12}{|c|}{ Specimen Collection Method } & \multirow{2}{*}{\multicolumn{2}{|c|}{ TT }} & \multirow{3}{*}{$\mathrm{P}$} \\
\hline & \multicolumn{2}{|c|}{$\mathrm{CF}$} & \multicolumn{2}{|c|}{ CAJH } & \multicolumn{2}{|c|}{ CTTNA } & \multicolumn{2}{|c|}{ CTBNA } & \multicolumn{2}{|c|}{ HTBLB } & \multicolumn{2}{|c|}{ HTTB } & & & \\
\hline & $\mathrm{n}$ & $\%$ & $\mathrm{n}$ & $\%$ & $\mathrm{n}$ & $\%$ & $\mathrm{n}$ & $\%$ & $\mathrm{n}$ & $\%$ & $\mathrm{n}$ & $\%$ & $\mathrm{n}$ & $\%$ & \\
\hline SCC & 62 & 78.5 & 3 & 3.8 & 5 & 6.3 & 1 & 1.3 & 7 & 8.9 & 1 & 1.3 & 79 & 100 & \\
\hline ADN & 161 & 69.4 & 20 & 8.6 & 17 & 7.3 & 20 & 8.6 & 6 & 2.6 & 8 & 3.4 & 232 & 100 & \\
\hline
\end{tabular}

Information: $\mathrm{HT}=$ Histology Type, $\mathrm{HTBLB}=$ Histopathology $T B L B, \mathrm{CF}=$ Cytology of Fluid, HTTB $=$ Histopathology TTB, $\mathrm{CAJH}=$ Cytology AJH, TT = Total, CTTNA = Cytology TTNA, $\mathrm{SCC}=$ Squamous cell carcinoma, $\mathrm{CTBNA}=$ Cytology TBNA, $\mathrm{ADN}=$ Adenocarcinoma, $\mathrm{P}=\mathrm{P}$ Value

In table 14, patients with both squamous cell carcinoma and adenocarcinoma, all were highest by taking liquid cytology specimens, 62 individuals (78.5\%) and 161 people (69.4\%) respectively. 


\section{Discussion}

The highest frequency of patient visits was in 2017 with 126 people (40.5\%) and 65-69 years age group with 70 people (22.5\%) [8]. The highest proportion of lung cancer patients by sex were 239 men (76.8\%) and 72 women (23.2\%) with sex ratio 3: 1 [2]. Highest occupation was 101 farmers $(32.5 \%)$ and the lowest were 18 pensioners (5.8\%) [9]. Highest residence was those who lived outside Medan City as many as 246 people $(79.1 \%)$ the rest lived in Medan City as many as 65 people (20.9\%). Highest main complaint was more than one complaint of 284 people (91.3\%) and the lowest was a cough of 13 people (4.2\%) [10]. Highest smoking history is those who have a smoking history of 259 people (83.3\%) than 52 people who do not smoke (16.7\%) [2]. Highest pleural effusion is 295 people (94.9\%) without pleural effusion and the lowest is pleural effusion of 16 people (5.1\%) [10]. Highest histology type was adenocarcinoma with 232 people $(74.6 \%)$ compared to squamous cell carcinoma with 79 people (25.4\%) [2]. Highest method of taking specimens was 223 liquid cytology (71.7\%) and the lowest histopathology of TTB was 9 people (2.9\%) [11]. Highest age group 35-39 and 40-44 years are women and the rest are males [8]. Highest men are farmers and the lowest is not working. Highest female sufferers are not working and the lowest are retirees [9]. Highest men are smokers $97.1 \%$ and in women, highest was who didn't smoke $62.5 \%$ [2]. Highest of all types of work was with more than one complaint [4]. Highest proportion of lung cancer sufferers who work as retirees, private employees, entrepreneurs, farmers and those not recorded is with a history of smoking, while those who do not work, highest are those who do not smoke [12]. Highest major complaints is with smoking [4]. Highest with both shortness of breath, coughing or more than one complaint, is where pleural effusion didn't occur [13]. Highest patients who smoke or didn't was adenocarcinoma [14]. The patients based on pleural effusion, highest was adenocarcinoma [15]. Highest with both squamous cell carcinoma and adenocarcinoma is the way to take liquid cytology specimens [16].

\section{Conclusion}

The tendency of inpatient lung cancer patients visiting H. Adam Malik General Hospital Medan in 2016-2018 decreased by 19 people (18.63\%). The highest proportion of lung cancer patients based on sociodemography was 65-69 years old with 70 patients $(22.5 \%), 239$ male patients (78.6\%) and 3: 1 sex ratio, with 101 farmers (32.5\%), who lived outside Medan City with 246 patients $(79.1 \%)$, the main complaint was more than one complaint with 284 patients $(91.3 \%)$, smoking history was smoking with 259 patients $(83.3 \%$ ), pleural effusion is without pleural effusion with 295 patients (94.9\%), the type of histology is adenocarcinoma with 232 patients (74.6\%), method of taking specimens is liquid cytology with 223 patients $(71.7 \%)$. There was a statistically significant relationship between age with sex, sex with occupation, sex with smoking history, occupation with primary complaints, occupation with smoking history, and histology type by specimen collection. There was no significant difference between the main complaint with 
smoking history, main complaint with pleural effusion, smoking history with histology type, pleural effusion with histology type.

\section{Acknowledgments}

The authors gratefully acknowledge that the present research is supported by Ministry of Research and Technology and the Higher Education Republic of Indonesia, Research and Community Service, Universitas Sumatera Utara.

\section{REFERENCES}

[1] A. F. Purba, and B. H. Wibisono, "Lung Cancer Clinical Pattern in Dr. Kariadi Semarang General Hospital during July 2013 - July 2014". Media Medika Muda, vol. 4, no. 4, pp.389-390. 2015.

[2] R. A. Ananda, S. Ermayanti, and Abdiana, "Relationship Between Lung Cancer Staging and Pain Scale in Lung Cancer Patients in DR M Djamil Padang General Hospital," Andalas Health Journal, vol. 7, no. 3, pp.1-3. 2018.

[3] A. Husen, C. H. Suharti, and Hardian, "Relationship Between Degree Of Pain With Quality Level of Life of Lung Cancer Patients Undergoing Chemotheraphy," Diponegoro Medical Journal, vol. 5, no. 4, pp.548-550. 2016.

[4] H. Alsagaff, "Lung Cancer and Palative Theraphy," Surabaya: Airlangga University Press. 1995.

[5] L. E. Raez, and O. E. Silva, "Lung Cancer, A Practical Guide," Philadelphia: Saunders Elsevier. 2008.

[6] W. D. Travis, E. Brambilla, A. P. Burke, A. Marx, and A. G. Nicholson. "WHO Classification Of Tumours Of The Lung, Pleura, Thymus and Heart," International Agency For Research On Cancer, vol. 4, pp.25-81. 2015.

[7] Ministry Health of Republic Indonesia, "Lung Cancer Management Guidelines," Ministry Health of Republic Indonesia, pp.2-7. 2017

[8] M. Butar, "Sociodemographic Characteristics of Inpatient Lung Cancer Patients In Dr. Pirngadi Hospital Medan Tahun 2005-2009," Adiwangsa University Public Health Study Program, pp.144-147. 2010.

[9] R. Oemiati, E. Rahajeng, \& A. Y. Kristanto (2009). "Tumour Prevalence And Some Factors That Influence It In Indonesia," Health Research and Development, pp.190-200. 2009.

[10] Adiatma, "Relationship Between Lung Carcinoma With Pleural Effusion," Journal Validation Sheet Media Medika Muda, pp.1-20. 2012.

[11] F. Kristina, T. Widjaja, and P. S. Martioso (2014). "Relationship of Pleural Cytology With Profile of Lung Cancer Patients in Immanuel Bandung Hospital during July 2010June 2013," lung cancer, pp.1-20. 2014.

[12] M. Amalia, "Analysis Of The Effect of Cigarette Consumption on Labour Productivity in Indonesia," ACC, pp.1-20. 2017.

[13] P. Ang, E. H. Tan, and S. S. Leong. "Primary Intrathoracic Malignant Effusion," National Cancer Center, pp.50-54. 2017.

[14] J. M. Samet, E. A. Tang, \& P. Bofetta, "Lung Cancer in Never Smokers: Clinical Epidemiology," American Association for Cancer Research, pp.5626-5640. 2009.

[15] F. Ramadhaniah, A. Mulawarman, and A. Suzanna, "Description of Lung Cancer Carcinoma of Not Small Cell," respiratory Journal, vol 36, no. 2, pp.60-64. 2016. 
[16] L. Wulandari and N. E. Faot, "Diagnostic Enforcement Problems For Patients With Lung Mass,” Respiratory Journal, vol. 3, no. 2, pp.41-46. 2017. 